\title{
Informatics at Russian Primary School
}

\author{
Marina S. TSVETKOVA \\ Academy of Improvement of Professional Skill and Professional Retraining of Educators \\ 8 Golovinskoe Shosse, Moscow 125212, Russian Federation \\ e-mail:ms-tsv@mail.ru
}

\begin{abstract}
The expedient and wide use of IT and the possibilities of modern educational information materials in the context of the intensification of information processes in society and education. Teaching younger students to use IT well is one of the important ways of developing academic activity and independence. Informatics as an academic subject at primary school is the main means of developing younger students' capacity for algorithmic thinking.
\end{abstract}

Keywords: informatics, primary school, skills younger school students on informatics, IT literacy.

\section{Introduction}

The Informatics as a subject is included at the Russian schools in the 90th years of the 20th century. Everywhere in the country, it has begun to be studied by younger school students (two or three years of studying) since 2005. Since 2012 informatics at primary school is included in the cluster of mathematical subjects. Before it was considered as a subject in the cluster of technological subjects of school.

Since 2009 in the new Russian school educational standard (Minobrnauki of Russia, 2009) in which not only studying in informatics is provided in a cluster of mathematical subjects (algorithmic thinking), but also the special program of IT teaching of children (IT literacy) in integration with other school subjects is entered. The informatics as a subject has two sections of contents - algorithmic and technological. The informatics course at school sets invariant requirements to competences of pupils, but the school can choose model of realization of a course taking into account resource providing. The number of Informatics lessons cannot be less than 70 hours for a course in primary school.

The planned results of learning of younger school students on informatics are given below: topics and number of lessons. Skills of pupils on each topic are specified. 


\section{Topic: Getting Acquainted with ICT Equipment and Computer Hygiene (6 Lessons)}

Students will learn:

- To use computers and other ICT facilities ergonomically in a way which does not endanger their organs of sight, nervous system or musculoskeletal system; perform desk exercises to compensate for a lack of physical movement.

- To organise a filing system for storing their own information on a computer.

\section{Topic: The Technology of Inputting Information onto a Computer: Inputting Text, Recording Sounds, Images and Numerical Data (10 Lessons)}

Students will learn:

- To master textual input using a keyboard.

- To input information into a computer using different technologies (photo- and video-cameras, microphones, etc.), and save the information obtained.

- To select short texts in their native language; to select short texts in a foreign language and use machine translation for separate words.

- To draw (create simple images) on a graphics tablet.

Students will have the opportunity to learn:

- To scan in drawings and texts.

- To use text recognition software for scanned text in Russian.

\section{Topic: Information Processing and Searches}

(18 Lessons)

Students will learn:

- To select a video or photo result suitable regarding content and technical quality, and use removable storage media (flash drives).

- To describe an object or observation according to a specific algorithm, and record audiovisual and numerical information about it using ICT tools.

- To compile numerical data from natural science observations and experiments using digital sensors, cameras, microphones and other technical items, and also from surveys of people.

- To edit texts, graphic images, slides in conjunction with communications or academic tasks, including textual editing, image chains, video and audio files and photo images.

- To use the main functions of a standard textual editor, and use a semiautomatic spellchecker; to use, add and remove links in messages of different types; to follow the basic rules of formatting a text.

- To search for information in age-appropriate digital dictionaries and manuals, in 
databases, on controlled internet, in the computer's internal search system; to compile a list of information sources used (including link usage).

- To populate a study database.

Students will have the chance to learn:

- How to accurately formulate queries when searching the internet and databases, and evaluate, interpret and save information which they find.

- To critically assess information and choice of information sources.

\section{Topic: Creating, Submitting and Sending Messages}

\section{(18 Lessons)}

Students will learn:

- To create text messages using ICT, and edit, format and save them.

- To create simple messages in the form of audio and video fragments or slide sequences using illustrations, video images, sounds and text.

- To prepare and give a presentation in front of a small audience: to create a presentation plan, select audiovisual support, write explanations and arguments for the presentation.

- To create schemes, plans, diagrams, etc.

- To create simple images using the graphic capabilities of a computer; to compile new images from ready-prepared fragments (application).

- To place a message in the educational information environment of an educational organisation.

- To use basic means of telecommunication; to take part in collective communication activities in an educational information environment, and to record the path and result of the communication on-screen and in files.

Students will have the opportunity to learn:

- How to present data.

- To create musical compositions using a computer and a music keyboard, including from ready-prepared musical fragments and music loops.

\section{Topic: Planning Activity, Management and Organisation (18 Lessons)}

Students will learn:

- To determine a sequence of completing actions, compile instructions (simple algorithms) for certain activities, build programs for a computer executor using sequence or repeat constructs.

- To create moveable models and control them using a computer (to create simple robots).

- To plan simple research of objects and processes in the outside world. 
Students will have the opportunity to learn:

- To project simple real-world objects and processes, their own activity and the activity of the group, including robotics projecting skills.

- To model real-world objects and processes.

\section{Conclusion}

Within 25 years of development of school informatics in Russia techniques of early learning of children in informatics were created. Now at each school of Russia informatics lessons at primary school are led. It helps early identification of talented children on informatics and their inclusion in Olympiad preparation.

The informatics course at primary school is added with electronic training materials on the website http://www.sc-edu.ru, interactive electronic notebooks and textbooks (for example, http://metodist.lbz.ru/authors/informatika/5/), manuals on informatics course (for example, http://metodist.lbz.ru/authors/ informatika/5/umk3-4.php).

The presented contents of a course of informatics at an elementary school are realized in programs of learning (Kuris and Tsvetkova, 2013) and textbooks for them which have passed the examination of the Ministry of Education and Science of Russia.

\section{References}

Minobrnauki of Russia (2009). Basic Educational Primary School Program. The Ministry of Education and Science of Russian Federation. (In Russian. Федеральный государственный образовательный стандарт начального общего образования, 1-4 кл.). Reference on 20.03.2016 from

http: //xn--80abucjiibhv9a. xn--p1ai/\%D0\%B4\%D0\%BE\%D0\%BA\%D1\%83\%D0\%BC\%D0\%B5\%D0\%BD\%D1\% $82 \%$ D $1 \% 8 \mathrm{~B} / 922$

Kuris, G.E., Tsvetkova, M.S. (2013). Informatics. Teaching Materials for Primary School: Grades 3-4. Methodological Manual for a Teacher. BINOM, Moscow, Laboratory of knowledge. (In Russian. Курис, Г.Э., Цветкова, М.С. Информатика. УМК для начальной школы [Электронный ресурс] : 3-4 классы. Методическое пособие для учителя). Reference on 20.03.2016 from:

http://files.lbz.ru/pdf/mpMogilev3-4fgos.pdf

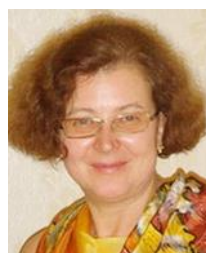

M.S. Tsvetkova, professor of the Russian Academy of Natural Sciences, $\mathrm{PhD}$ in pedagogic science, prize-winner of competition "The Teacher of Year of Moscow" (1998), main expert of state projects of school education informatization in the Ministry of Education of the Russian Federation (2001-2005), the expert of the World bank project "Informatization of Education System". Since 2002 she is a member of the Central methodical commission of the Russian Olympiad in informatics, the pedagogic coach of the Russian team on the IOI. She is the author of many papers and books in Russia on the informatization of education and methods of development of talented students. Since 2013 she is the Russian team leader. 